einstein

Official Publication of the Instituto Israelita

de Ensino e Pesquisa Albert Einstein

ISSN: 1679-4508 | e-ISSN: 2317-6385

\title{
Treatment of ligneous conjunctivitis with heterologous serum
}

\section{Tratamento de conjuntivite lenhosa com soro heterólogo}

Thiago Gonçalves dos Santos Martins'1, Thomaz Gonçalves dos Santos Martins², Diogo Gonçalves dos Santos Martins², Maria Carolina Francisco Kuba²

${ }^{1}$ Universidade Federal de São Paulo, São Paulo, SP, Brazil.

2 Universidade Estácio de Sá, Rio de Janeiro, RJ, Brazil.

DOI: 10.31744/einstein_journal/2019RC4714

\section{$\triangle$ ABSTRACT}

Ligneous conjunctivitis is a rare form of chronic and recurrent bilateral conjunctivitis, in which thick membranes develop on the tarsal conjunctiva and on other mucosae. We report the case of a 55-year old female patient with bilateral ligneous conjunctivitis who was successfully treated with $50 \%$ heterologous serum. There was no recurrence or side effects after one-year follow-up. We suggest the use of $50 \%$ heterologous serum should be further studied to better determine its efficacy as a treatment option for ligneous conjunctivitis.

Keywords: Serum; Conjunctivitis/therapy; Plasminogen/deficiency

\section{RESUMO}

A conjuntivite lenhosa é uma forma rara de conjuntivite bilateral crônica e recorrente, na qual há formação de membranas espessas na conjuntiva tarsal e em outras mucosas. Relatamos 0 caso de uma paciente de 55 anos com conjuntivite lenhosa bilateral, que obteve sucesso no tratamento com soro heterólogo em concentração de $50 \%$. Não houve recorrência após um ano de seguimento e nem efeitos colaterais ao tratamento. Dessa forma, o uso de soro heterólogo a $50 \%$ poderia ser mais estudado para melhor avaliação de sua eficácia como opção de tratamento para a conjuntivite lenhosa.

How to cite this article:
Martins TG, Martins TG, Martins DG, Kuba MC. Treatment of ligneous conjunctivitis with heterologous serum. einstein (São Paulo). 2019;17(3):eRC4714. http://dx.doi.org/ 10.31744/einstein journal/2019RC4714

Corresponding author:

Thiago Gonçalves dos Santos Martins Rua Botucatu, 822 - Vila Clementino Zip code: 04039-032 - São Paulo, SP, Brazil Phone: (55 11) 5085-2010

E-mail: thiagogsmartins@yahoo.com.br

Received on:

July, 26, 2018

\section{Accepted on:}

Dec 20, 2018

\section{Copyright 2019}

\section{(c) By}

This content is licensed

under a Creative Commons

Attribution 4.0 International License.
Descritores: Soro; Conjuntivite/terapia; Plasminogênio/deficiência

\section{INTRODUCTION}

Ligneous conjunctivitis is a chronic condition that may be triggered by ocular trauma or surgeries in patients presenting type I plasminogen deficiency. ${ }^{(1,2)}$ The incidence in the general population of type I plasminogen deficiency is 16 cases per 1,000,000 individuals. ${ }^{(1)}$ The presence of the fibrin-rich pseudomembrane on the tarsal conjunctiva is the typical lesion of ligneous conjunctivitis. The bilateral ocular form is present in $51 \%$ of cases, and corneal complications leading to blindness are present in 20 to $30 \%$ of patients. ${ }^{(1)}$ Ligneous conjunctivitis treatment is challenging and only partially effective. Treatment using plasminogen, heparin and topical cyclosporine A can be employed. ${ }^{(3,4)}$ We describe a case of ligneous conjunctivitis with successful therapeutic response to $50 \%$ heterologous serum.

\section{CASE REPORT}

A 55-year-old female patient referred a history of 6-month conjunctivitis not responding to ocular lubricant solutions, $0.3 \%$ tobramycin or surgical 
excision of pseudomembranes. The patient was referred to the Department of Ophthalmology of the Universidade Federal de São Paulo and diagnosed as ligneous conjunctivitis associated with systemic plasminogen deficiency. At the first appointment at the service, she presented ocular hyperemia and thick pseudomembranes on tarsal conjunctivae of both eyes (Figure 1).
Treatment was initiated using ocular solution with $50 \%$ heterologous serum, obtained from the brother of the patient, instilled every 3 hours during 2 months, with improvement of symptoms after this period of treatment (Figure 2).

The $50 \%$ heterologous serum ocular solution was discontinued after one-year use and no ligneous conjunctivitis recurrence was reported.
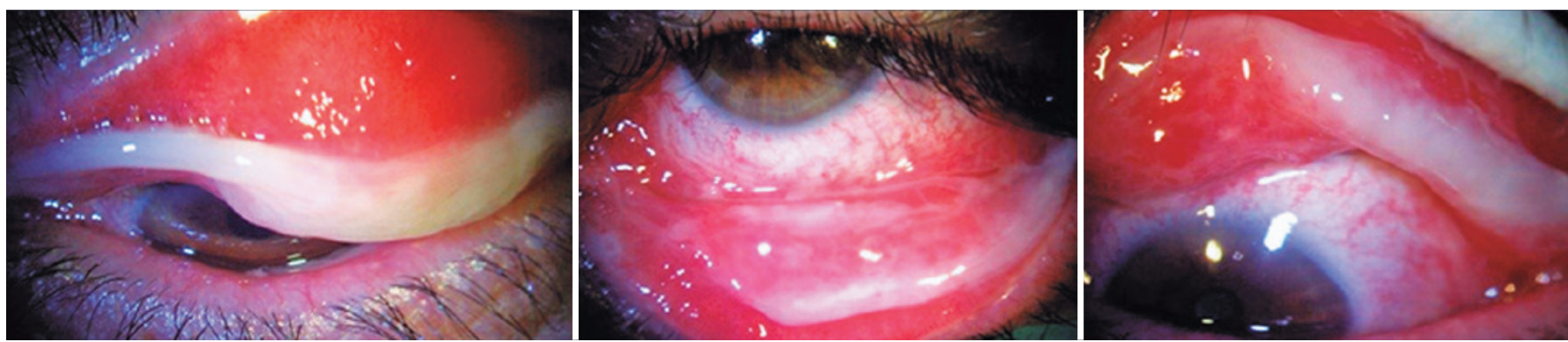

Figure 1. Ligneous conjunctivitis with pseudomembrane in both eyes
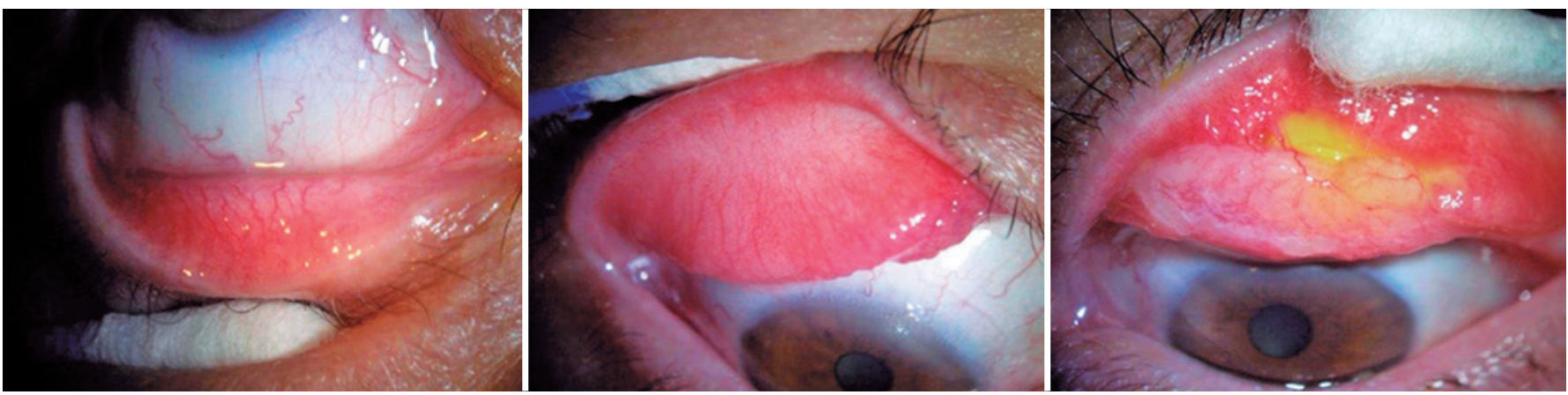

Figure 2. Improved eye condition after treatment with $50 \%$ heterologous serum

\section{DISCUSSION}

Patients with ligneous conjunctivitis have deficiency in plasminogen, which is necessary for fibrinolysis in the wound healing process. ${ }^{(5)}$ Genetic studies performed in 38 patients with ligneous conjunctivitis revealed different mutations in the plasminogen gene. The K19E gene is the most frequent genetic variation and it was found in $34 \%$ of patients. ${ }^{(6)}$

Since plasminogen is the main factor responsible for fibrin degradation, plasminogen deficiency leads to accumulation of fibrinous material and development of pseudomembranes on mucosal surfaces, such as the tarsal conjunctiva. There is no optimal treatment for ligneous conjunctivitis, and surgery, fibrinolysis or anticoagulation, and immunomodulation can be performed. During surgical treatment additional trauma should be avoided and hemostasis should be carefully performed to avoid fibrin deposition. Heparin administration prevents fibrin formation and recurrence of pseudomembranes. ${ }^{(7,8)}$ Immunomodulatory therapy with corticosteroids and cyclosporine can be used in the treatment. ${ }^{(9)}$

Hypoplasminogenemia is a systemic condition, which can affect other mucosae, such as in the respiratory, gastrointestinal and genitourinary tract. Ligneous conjunctivitis is a rare ocular manifestation in patients with hypoplasminemia. Early diagnosis and treatment are important to prevent permanent damage to the ocular surface of patients.

Human heterologous serum contains substances such as growth factors, vitamin A, fibronectin, cytokines, and plasminogen, which may have helped the degradation 
of the fibrin membranes on the tarsal conjunctiva of our patient, although further studies are required. ${ }^{(10)}$

Most topical treatments do not produce optimal results for ligneous conjunctivitis:

- Hyaluronidase alone $(1.5 \mathrm{mg} / \mathrm{mL})$ or in combination with alpha-chymotrypsin $(0.2 \mathrm{mg} / \mathrm{mL})$ can be used for the enzymatic digestion of the mucopolysaccharides that exist on the pseudomembranes..$^{(9,10)}$

- Topical treatment with topical corticosteroids and $2 \%$ cyclosporin A may decrease the recurrence of pseudomembranes after surgical excision..$^{(9,10)}$

- Surgical excision of the pseudomembrane can be associated with the administration of topical heparin $(1,000$ or 5,000 units $/ \mathrm{mL})$ and $1 \%$ topical prednisolone. ${ }^{(10)}$ Heparin accelerates the activity of antithrombin III, which inhibits thrombin formation, blocking the conversion of fibrinogen to fibrin. Heparin also neutralizes factor $\mathrm{Xa}$, preventing the transformation of thrombin into prothrombin. Corticosteroids reduce conjunctival inflammation. Topical heparin reduces recurrence, compared with surgical excision only. ${ }^{(10)}$

Topical concentrated plasminogen $(1 \mathrm{mg} / \mathrm{mL})$ obtained from plasma as eye drops, applied every 2 hours for 3 to 4 weeks has been described, with reported satisfactory outcome after one year of treatment. ${ }^{(10)}$ Plasminogen in the form of lys-plasminogen can also be administered intravenously using a deep venous catheter at the dose of $180 \mathrm{U} / \mathrm{kg}$ of body weight per day, for 2 weeks, with decreasing doses of 180 to $125 \mathrm{U} / \mathrm{kg}$ body weight/ day, leading to improvement in the condition after 4 weeks of treatment. ${ }^{(10)}$ Systemic treatment improves pseudomembranes of other affected mucosae. ${ }^{(10)}$

\section{- CONCLUSION}

Ligneous conjunctivitis is a chronic condition in patients with type 1 plasminogen deficiency. Its management is challenging and no fully-effective treatment has been demonstrated. We report a case of ligneous conjunctivitis with satisfactory outcome after treatment with $50 \%$ heterologous serum. There was no recurrence and no side effects after one-year follow-up. The use of $50 \%$ heterologous serum should be evaluated as an alternative treatment for ligneous conjunctivitis.

\section{ACKNOWLEDGENTS}

To Professor Denise de Freitas.

\section{AUTHORS' INFORMATION}

Martins TG: http://orcid.org/0000-0002-3878-8564

Martins TG: http://orcid.org/0000-0001-5440-8149

Martins DG: http://orcid.org/0000-0002-6881-5359

Kuba MC: http://orcid.org/0000-0001-6606-4996

\section{REFERENCES}

1. Schuster V, Seregard S. Ligneous conjunctivitis. Surv Ophthalmol. 2003; 48(4):369-88.

2. Schuster V, Hügle B, Tefs K. Plasminogen deficiency. J Thromb Haemost. 2007;5(12):2315-22.

3. Heidemann DG, Williams GA, Hartzer M, Ohanian A, Citron ME. Treatment of ligneous conjunctivitis with topical plasmin and topical plasminogen. Cornea. 2003;22(8):760-2.

4. Azad N, Zafar S, Khan A. Successful treatment of ligneous conjunctivitis with topical cyclosporine and heparin. J AAPOS. 2009;13(5):519-20.

5. Schäfer BM, Maier K, Eickhoff U, Todd RF, Kramer MD. Plasminogen activation in healing human wounds. Am J Pathol. 1994;144(6):1269-80.

6. Tefs K, Gueorguieva M, Klammt J, Allen CM, Aktas D, Anlar FY, et al. Molecular and clinical spectrum of type I plasminogen deficiency: a series of 50 patients. Blood. 2006;108(9):3021-6.

7. Hiremath M, Elder J, Newall F, Mitchell S, Dyas R, Monagle P. Heparin in the long-term management of ligneous conjunctivitis: a case report and review of literature. Blood Coagul Fibrinolysis. 2011;22(7):606-9.

8. De Cock R, Ficker LA, Dart JG, Garner A, Wright P. Topical heparin in the treatment of ligneous conjunctivitis. Ophthalmology. 1995;102(11):1654-9.

9. Azad N, Zafar S, Khan A. Successful treatment of ligneous conjunctivitis with topical cyclosporine and heparin. J AAPOS. 2009;13(5):519-20.

10. López-García JS, García-Lozano I, Rivas L, Martínez-Garchitorena J. [Use of autologous serum in ophthalmic practice]. Arch Soc Esp Oftalmol. 2007; 82(1):9-20. Review. Spanish. 